\title{
Effects of Ruzu Herbal Bitters, a Traditional Nigerian Polyherbal Drug, on Longevity and Selected Toxicological Indices in Drosophila melanogaster
}

\author{
Zeniat Oyaluna $^{1,2}$ (D), Amos Olalekan Abolaji ${ }^{3, * \mathbb{C}}$, Chinedum Peace Babalola $\left.1,2, * \mathbb{( D}\right)$
}

1 Department of Pharmaceutical Chemistry Faculty of Pharmacy, University of Ibadan, Nigeria; oyalunazeniat@yahoo.com (Z.O.); peacebab@gmail.com (C.P.B.);

2 Centre for Drug Discovery Development \& Production (CDDDP), Faculty of Pharmacy, University of Ibadan, Nigeria

3 Drosophila Laboratory, Department of Biochemistry, Drug Metabolism and Toxicology Unit, Faculty of Basic Medical Sciences, College of Medicine, University of Ibadan, Ibadan, Nigeria; amos_abolaji@yahoo.com; ao.abolaji@ui.edu.ng (A.O.A.);

* Correspondence: peacebab@gmail.com (C.P.B); amos_abolaji@yahoo.com; ao.abolaji@ui.edu.ng (A.O.A.);

Scopus Author ID 6603752472 (C.P.B.); 24334109900 (A.O.A.);

Received: 24.07.2020; Revised: 10.09.2020; Accepted: 12.09.2020; Published: 15.09.2020

\begin{abstract}
There is a steady rise in human consumption of herbal mixtures, particularly in developing countries. This has led to the constant demand for safety evaluation of herbal mixtures by regulatory bodies. Here, the fruit fly, Drosophila melanogaster was used for the safety evaluation of Ruzu Herbal Bitters, a polyherbal mixture. Firstly, 14 days of survival followed by longevity studies were carried out on flies treated with Ruzu $(0,20,40$, and $60 \mu \mathrm{L} / \mathrm{g}$ diet $)$. Then a similar treatment was carried out for 5 days to assess selected biochemical markers. The results showed no significant effect was noticed on the survival rate of the fruit fly. Long-term exposure showed that Ruzu ( $40 \mu \mathrm{L} / \mathrm{g}$ diet) increased the lifespan of flies by $6 \%$, while $60 \mu \mathrm{L} / \mathrm{g}$ diet reduced their lifespan by 13\%. Ruzu Herbal bitters did not alter the negative geotaxis, acetylcholinesterase, and glutathione-S-transferase activities in flies. Nitric oxide level was unaffected, except at an extreme concentration of $60 \mu \mathrm{L} / \mathrm{g}$ diet. Moreover, Ruzu (20 $\mu \mathrm{L} / \mathrm{g}$ diet) significantly increased the total thiol level. The glucose level was also significantly reduced. Our data thus suggest that short term consumption of moderate doses of Ruzu Herbal Bitters might be safe for oral consumption. The hypoglycaemic property observed here may imply that it might be used as an antidiabetic drug.
\end{abstract}

Keywords: Drosophila; Phytochemicals; Longevity; Antioxidants; Negative geotaxis; Glucose.

(C) 2020 by the authors. This article is an open-access article distributed under the terms and conditions of the Creative Commons Attribution (CC BY) license (https://creativecommons.org/licenses/by/4.0/).

\section{Introduction}

Herbal mixtures are parts of plants extracted with appropriate solvents like water or ethanol. Despite the accessibility of contemporary drugs, plants are still being used globally as medicines [1,2]. Additionally, about $80 \%$ of people in developing nations still rely on herbal drugs $[3,4]$. Furthermore, in countries like Nigeria, plant-based drugs are normally sold as herbal bitters with a characteristic sour taste [5].

In Nigeria, Ruzu Herbal bitters are commonly used for the treatment of obesity, diabetes, arthritis, hypertension, and infertility. The main components are the root of Curculigo pilosa (Squirrel Groundnut), the stem of Uvaria chamae (Bush Banana), and the bark of Citrullus colocynthis (Bitter Apple or Desert Gourd) [6]. 
There is an ongoing search for an appropriate and reliable model organism to assess the safety of herbal drugs [7]. In this context, Drosophila melanogaster (fruit fly) can be considered as a novel organism for the safety evaluation of herbal drugs [8] for several reasons. For instance, about $75 \%$ of human disease-causing genes have functional homology in Drosophila [9]. Drosophila is less expensive, easy to maintain, and has a short lifespan [10]. The fly also has fewer ethical restrictions compared with other models like rodents [11].

Considering the global usage of herbal drugs [12,13], government agencies are confronted with the challenge of ensuring that they are safe for consumption [14]. In this study, therefore, we utilized $D$. melanogaster to evaluate the safety of Ruzu herbal bitters with respect to effects on longevity and selected toxicological markers.

\section{Materials and Methods}

\subsection{Herbal mixtures.}

Ruzu Herbal bitters were purchased from a Community Pharmacy in Ibadan, Nigeria. Ruzu Herbal bitters are registered under The National Agency for Food and Drug Administration and Control (NAFDAC) with the Registration number A7-1102L. The active ingredients are the root of Curculigo pilosa (Squirrel Groundnut, $40 \% \mathrm{w} / \mathrm{v}$ ), the stem of Uvaria chamae (Bush Banana, 20\% w/v), and the bark of Citrullus colocynthis (Bitter apple or Desert Gourd, $40 \% \mathrm{w} / \mathrm{v})$.

\subsection{Fly strain.}

The Harwich strain of D. melanogaster was maintained in Drosophila Laboratory, Department of Biochemistry, University of Ibadan, Nigeria at constant temperature and humidity $\left(23 \pm 2^{\circ} \mathrm{C} ; 60 \%\right.$ relative humidity, respectively) under $12 \mathrm{~h}$ dark/light cycle. The standard Drosophila medium used is composed of cornmeal $(1 \% \mathrm{w} / \mathrm{v})$, brewer's yeast $(2 \%$ w/v), agar, and nipagin $(0.08 \%)$.

\subsection{Herbal mixture exposure, longevity, and survival assays.}

For longevity and survival assays, D. melanogaster (1-3 days old, with 30 flies per/vial per group, $\mathrm{n}=3$ ) were starved for 4 hours prior to exposure to 20,40 , and $60 \mu \mathrm{L} / \mathrm{g}$ diets of Ruzu Herbal Bitters. The daily mortality was recorded and used to calculate the percentage of live flies $[15,16]$.

\subsection{Behaviour (negative geotaxis) assay.}

This was carried out using the negative geotaxis assay, as previously described by Abolaji et al. [17,18]. Here, ten (10) flies from the control and treated groups were immobilized with ice as anesthesia and placed in labeled vertical glass columns. They were allowed to recover and gently tapped to the bottom of the column. The number of flies that climbed up to the $6 \mathrm{~cm}$ mark in $6 \mathrm{~s}$ and the flies below this mark was recorded and expressed as a percentage of the control.

\subsection{Sample preparation for selected toxicological markers.}

Flies were placed in four groups, with each group containing 1-3 days old fly, 30 flies/vial, and starved for 4 hours before being exposed to Ruzu Herbal Bitters (0, 20, 40, and 
$60 \mu \mathrm{L} / \mathrm{g}$ diet) for 5 days. Then, flies were anesthetized in ice, weighed and homogenized in 0.1 M phosphate buffer, pH 7.0 ( $1 \mathrm{mg}: 10 \mu \mathrm{l})$, and centrifuged for $10 \mathrm{~min}$ at $4000 \mathrm{~g}\left(4^{\circ} \mathrm{C}\right)$. Then, supernatants were separated and used to determine glutathione S-transferase and acetylcholinesterase activities as well as nitric oxide and total thiol levels. For the glucose assay, the flies were homogenized in glucose/trehalose buffer ( $5 \mathrm{mM}$ Tris ( $\mathrm{pH}$ 6.6), $2.7 \mathrm{mM}$ $\mathrm{KCl}, 137 \mathrm{mM} \mathrm{NaCl}$ ). The supernatant was then used for the determination of glucose level in the flies.

\subsection{Determination of total thiols.}

The total thiol level was determined based on the method of Ellman [19]. The reaction mixture was made up of $270 \mu \mathrm{L}$ of $0.1 \mathrm{M}$ of potassium phosphate buffer with a $\mathrm{pH} 7.4,20 \mu \mathrm{L}$ of the sample, and $10 \mu \mathrm{L}$ of $10 \mathrm{mM} \mathrm{5,5'-dithiobis-(2-nitrobenzoic} \mathrm{acid).} \mathrm{This} \mathrm{was} \mathrm{followed} \mathrm{by}$ an incubation period of $30 \mathrm{~min}$ at room temperature. The absorbance was then measured at a wavelength of $412 \mathrm{~nm}$. The total thiol content was calculated using GSH as standard and expressed in $\mu \mathrm{mol} / \mathrm{mg}$ protein.

\subsection{Determination of glutathione-S-transferase (GST) activity.}

The glutathione-S-transferase activity was determined with the method of Habig and Jakoby [20]. This involved the use of 1-chloro-2,4-dinitrobenzene (CDNB) as a substrate. The reaction mixture contained $190 \mu \mathrm{L}$ of solution A ( $20 \mathrm{ml}$ of $0.25 \mathrm{M}$ phosphate buffer containing $2.5 \mathrm{mM}$ EDTA, $10.5 \mathrm{ml}$ distilled water and $500 \mu \mathrm{L}$ of $0.1 \mathrm{M} \mathrm{GSH}), 20 \mu \mathrm{L}$ of sample, and 10 $\mu \mathrm{L}$ of $25 \mathrm{mM}$ CDNB. The mixture was mixed, and the absorbance was read at $340 \mathrm{~nm}$ for 5 mins at 10 seconds interval. The data were then expressed in $\mathrm{mmol} / \mathrm{min} / \mathrm{mg}$ of protein using the molar extinction coefficient $(\varepsilon)$ of $9.6 \mathrm{mM}^{-1} \mathrm{~cm}^{-1}$ for the colored GS- DNB conjugate formed by GST.

\subsection{Determination of acetylcholinesterase activity (AChE).}

The activity of acetylcholinesterase was determined using the method of Ellman et al. [21]. Briefly, the reaction mixture contained $135 \mu \mathrm{L}$ of distilled water, $20 \mu \mathrm{L}$ of $100 \mathrm{mM}$ potassium phosphate buffer (pH 7.4), $20 \mu \mathrm{L}$ of $10 \mathrm{mM}$ DTNB, $5 \mu \mathrm{L}$ of the sample, and $20 \mu \mathrm{L}$ of $8 \mathrm{mM}$ acetylthiocholine. The reaction was thereafter monitored at a wavelength of $412 \mathrm{~nm}$ for $5 \mathrm{~min}$ at $15 \mathrm{~s}$ intervals. The data were expressed in $\mu \mathrm{mol} / \mathrm{min} / \mathrm{mg}$ protein.

\subsection{Determination of nitric oxide level.}

The amount of nitrite in the homogenate was measured following the Griess reaction [22]. Fly homogenate $(250 \mu \mathrm{l})$ was incubated with $250 \mathrm{ul}$ of Griess reagent $(0.1 \% \mathrm{~N}-(1-$ naphthyl) ethylenediamine dihydrochloride; $1 \%$ sulfanilamide in $5 \%$ phosphoric acid; $1: 1$ ) at room temperature for $20 \mathrm{~min}$. The absorbance was read at $550 \mathrm{~nm}$ in a spectrophotometer. The nitrite/nitrate concentration was calculated using sodium nitrite as standard.

\subsection{Determination of glucose level.}

Flies were homogenized in glucose/trehalose buffer ( $5 \mathrm{mM}$ Tris ( $\mathrm{pH} .6) 2.7 \mathrm{mM} \mathrm{KCl}$, $137 \mathrm{mM} \mathrm{NaCl}$, to prevent pre-oxidation of the glucose. The homogenate was then centrifuged at $4000 \mathrm{~g}$ for $10 \mathrm{mins}$. The glucose level was measured after incubation at $37^{\circ} \mathrm{C}$ for $25 \mathrm{~min}$ using 
a Randox glucose kit and processed as per the manufacturer's instructions. Glucose concentration was calculated against the standard in $\mathrm{mg} / \mathrm{dl}[23]$.

\subsection{Statistical analysis.}

Data were expressed as mean \pm standard deviation and analyzed using One-way ANOVA. A $95 \%$ confidence of $(p<0.05)$ was used to determine statistically significant differences between treated and control groups.

\section{Results and Discussion}

\subsection{Results.}

3.1.1. Effects of ruzu herbal bitters on longevity, survival rate, and behavior of D. melanogaster exposed to ruzu herbal bitters for 5 days.

Figure 1 shows the effects of Ruzu Herbal Biters on longevity and survival rate of $D$. melanogaster after 5 days of treatment. Ruzu Herbal bitters at a dose of $40 \mu \mathrm{L} / \mathrm{g}$ diet increased the lifespan of D. melanogaster by $6 \%$ compared to control (Figure 1A). There was no statistically significant difference in the survival rate of flies exposed to Ruzu Herbal Bitters for 14 days (Figure 1B, $p>0.05$ ).

Figure 2 shows the effects of Ruzu Herbal Bitters on the behavior of D. melanogaster after 5 days of treatment. There was no significant difference in the locomotive behavior (Figure 2A) and acetylcholinesterase activity (Figure 2B) of flies treated with Ruzu compared with the control $(\mathrm{p}>0.05)$.

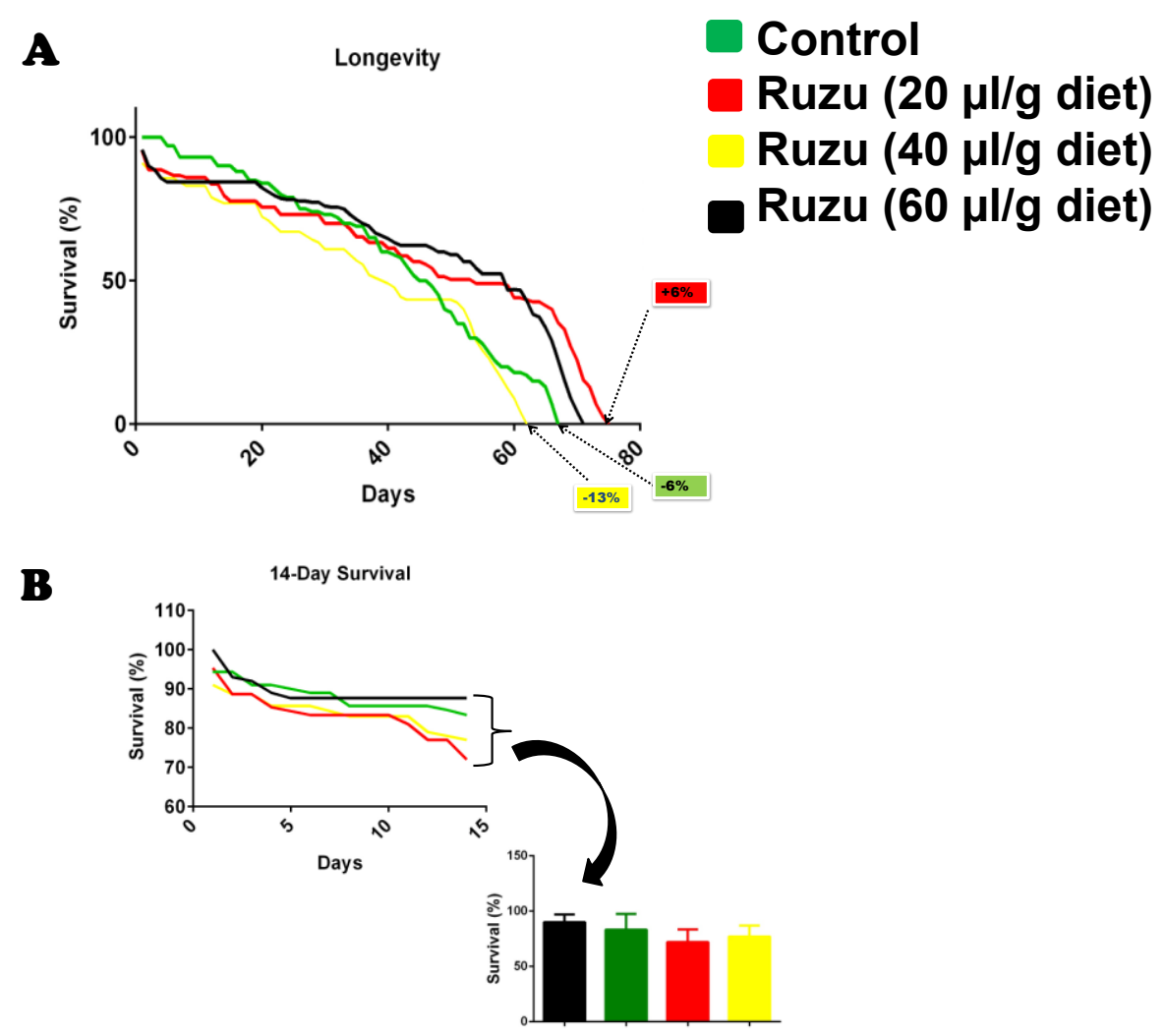

Figure 1. Effects of Ruzu Herbal Bitters on the survival of D. melanogaster. Longevity (A) and 14 Days survival (B) of D. melanogaster treated with Ruzu Herbal Bitters for 5 days. Ruzu Herbal Biters (40 u/g diet) extends the lifespan of flies by $6 \%$. There was no statistically significant difference between survival data of Ruzu-treated and control flies $(\mathrm{p}>0.05)$. Data are expressed as mean \pm standard deviation, 30 flies per/vial, $n=3$ ) 


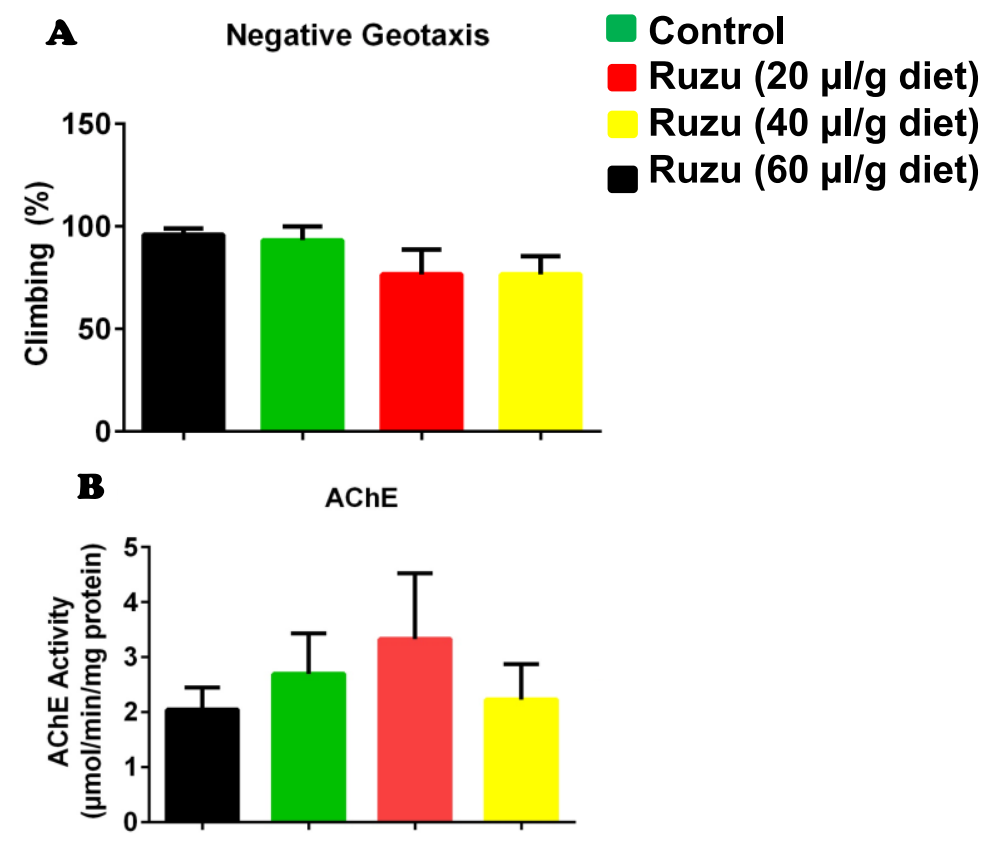

Figure 2. Effects of Ruzu Herbal Bitters on the Behaviour of D. melanogaster. Negative geotaxis (A) and acetylcholinesterase activity (B) of D. melanogaster exposed to Ruzu Herbal Bitters for 5 days. Data are expressed as mean \pm standard deviation with no significant difference compared with control, $\mathrm{p}>0.05 ; 30$ flies/vial, $n=3$.

3.1.2. Effects of ruzu herbal bitters on selected toxicological markers and glucose level of $D$. melanogaster.

The effects of Ruzu Herbal Bitters on selected toxicological markers and glucose levels are shown in Figure 3. Ruzu Herbal Bitters at doses of 20 and $60 \mu \mathrm{L} / \mathrm{g}$ diets increased total thiol level compared with the control (Figure 3A, $\mathrm{p}<0.05$ ). The level of nitric oxide decreased in flies treated with Ruzu ( $60 \mu \mathrm{L} / \mathrm{g}$ diet). In addition, glucose level was lowered in flies exposed to Ruzu $(20 \mu \mathrm{L} / \mathrm{g}$ diet, $\mathrm{p}<0.05)$, while there was no change in the activity of GST in all the groups exposed to Ruzu ( $\mathrm{p}>0.05)$.

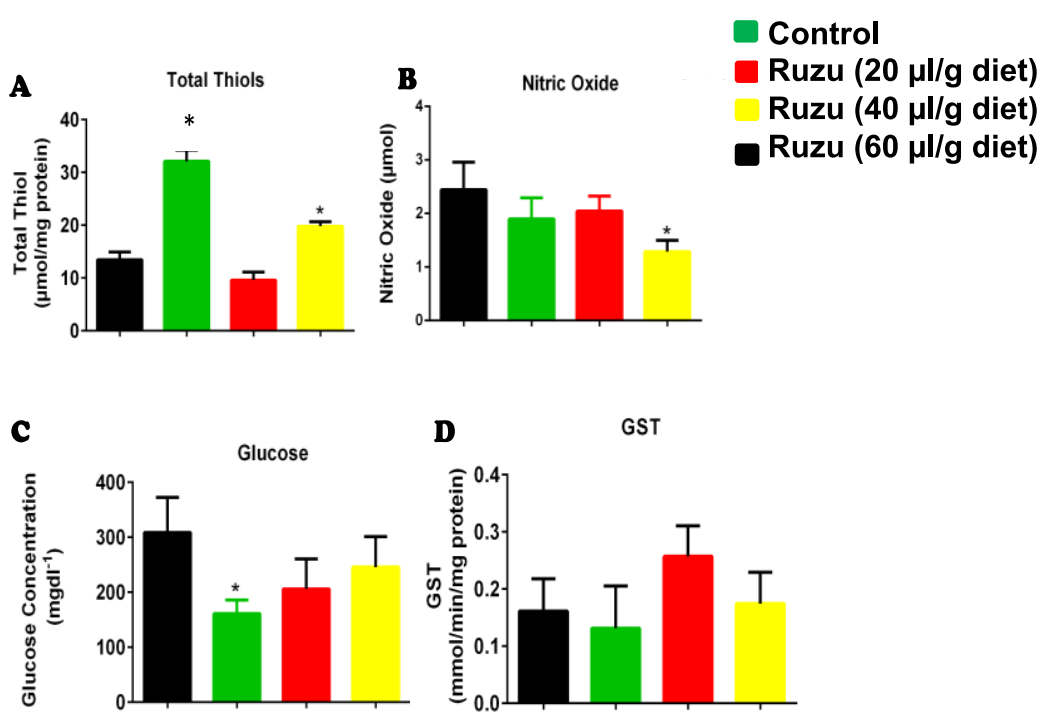

Figure 3. Effects of Ruzu Herbal Bitters on selected toxicological markers in D. melanogaster. Levels of Total thiol (A), Nitric Oxide (B), and Glucose (C) as well as activity of GST (D) in D. melanogaster exposed to Ruzu Herbal Bitters for 5 days. Data are expressed as mean \pm standard deviation. *Indicates Significant difference compared with control at $\mathrm{p}<0.05 ; \mathrm{n}=3,30$ flies/vial. 


\subsection{Discussion.}

Since ancient times, plants have been used as sources of food and drugs [24]. Herbal mixtures have a global market of about 60 billion dollars [25]. Regulatory bodies are therefore faced with the challenge of ensuring that herbal drugs are safe for consumption irrespective of efficacy. This study was carried out to evaluate the safety assessment of Ruzu Herbal Bitters in D. melanogaster.

The normal physiological activity of an organism is reflected in its behavior. The climbing activity (negative geotaxis) and acetylcholinesterase (AChE) activity coordinate the behavior of D. melanogaster [26]. Acetylcholinesterase catalyzes the breakdown of acetylcholine to acetate and choline. Acetylcholine participates in the regulation of locomotion, motor function, and memory [27]. Here, we found that Ruzu Herbal bitters did not significantly affect the behaviour and acetylcholinesterase activity of $D$. melanogaster, thus indicating that the behavior of the flies was not altered after exposure to the drug.

We sought to understand the effects of Ruzu Herbal bitters on the antioxidant status and nitric oxide level of $D$. melanogaster. Toxicological markers such as glutathione Stransferase (GST) activity and total thiols and nitric oxide levels are useful markers of accessing the general well-being of an organism. For instance, sulfhydryl (-SH) group in thiolscontaining compounds and proteins can easily conjugate with free radicals and electrophiles in order to inactivate and convert them into less harmful forms [28,29]. In addition, nitric oxide is a signaling molecule in numerous physiological processes, including immunity and neuronal activity in D. melanogaster [30]. The observation that Ruzu caused a boost in the total thiols level without affecting GST activity showed its beneficial effects in the flies.

The fact that Ruzu significantly reduced glucose level showed that it has hypoglycaemic properties, which may be responsible for its wide usage as an antidiabetic herbal mixture [31].

\section{Conclusions}

A moderate dosage of Ruzu herbal bitters for a short term period did not have adverse effects with respect to the flies (Scheme 1). The polyherbal mixture also has hypoglycaemic properties. However, long-term consumption of high doses may have some adverse effects, as indicated by the longevity data.

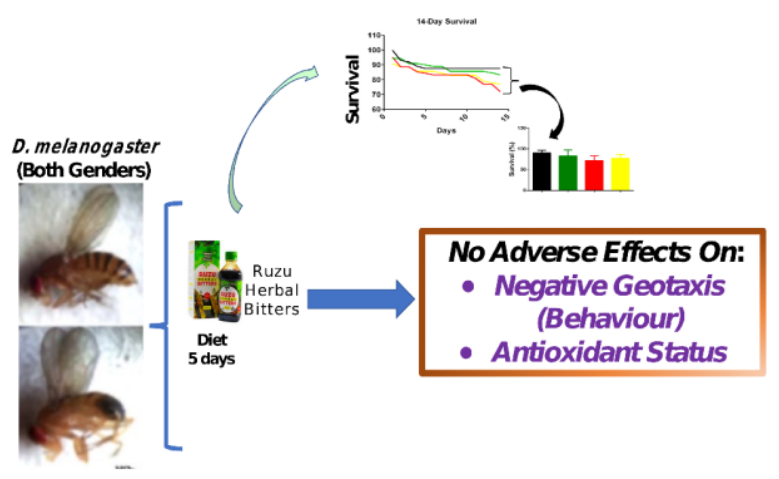

Scheme 1. Summary of safety assessment of Ruzu Herbal Bitters using D. melanogaster as a model. There were no adverse effects on the survival, behavior, and antioxidant status of $D$. melanogaster exposed to moderate doses of Ruzu Herbal Bitters. 


\section{Funding}

This research received no external funding.

\section{Acknowledgments}

This research has no acknowledgment.

\section{Conflicts of Interest}

The authors declare no conflict of interest.

\section{References}

1. Kokoska, L.; Kloucek, P.; Leuner, O.; Novy, P. Plant-derived products as antibacterial and antifungal agents in human health care. Curr Med Chem 2019, 26, 5501-5541, https://doi.org/10.2174/0929867325666180831144344.

2. Kumar, S.V.; Das, S.; Kumar, D.A.; Kumar, C.A.; Upadhyay, N.; Dubey, N.K. Assessment of chemically characterized Salvia sclarea L. essential oil and its combination with linalyl acetate as novel plant-based antifungal, antiaflatoxigenic and antioxidant agent against herbal drugs contamination and probable mode of action. Nat Prod Res 2019, https://doi.org/10.1080/14786419.2019.1593168.

3. Oguntibeju, O.O. Medicinal plants and their effects on diabetic wound healing. Vet World 2019, 12, 653663, https://doi.org/10.14202/vetworld.2019.653-663.

4. WHO. WHO Traditional Medicine Strategy 2002-2005, 2002.

5. Ezekwesili-Ofili, J.O.; Okaka, A.N.C. Chapter 10-Herbal Medicines in African Traditional Medicine. Intechopen Book 2019, 191-214.

6. Kale, O.E.; Akinpelu, O.B.; Bakare, A.A.; Yusuf, F.O.; Gomba, R.; Araka, D.C.; Ogundare, T.O.; Okolie, A.C.; Adebawo, O.; Odutola, O. Five traditional Nigerian polyherbal remedies protect against high fructose fed, Streptozotocin-induced type 2 diabetes in male Wistar rats. BMC Complement Altern Med 2018, 18, 160. https://doi.org/10.1186/s12906-018-2225-6.

7. Villas Boas, G.R.; Rodrigues Lemos, J.M.; de Oliveira, M.W.; dos Santos, R.C.; Stefanello da Silveira, A.P.; Barbieri Bacha, F.; Ito, C.N.A.; Bortolotte Cornelius, E.; Brioli Lima, F.; Sachilarid Rodrigues, A.M.; Belmal Costa, N.; Francisco Bittencourt, F.; Freitas de Lima, F.; Meirelles Paes, M.; Gubert, P.; Oesterreich, S.A. Aqueous extract from Mangifera indica Linn. (Anacardiaceae) leaves exerts long-term hypoglycemic effect, increases insulin sensitivity and plasma insulin levels on diabetic Wistar rats. PLoS One 2020, 15, https://doi.org/10.1371/journal.pone.0227105.

8. Villas Boas, G.R.; Souza de Araújo, F.H.; Moreira Marcelino, J.; Almeida Castro, L.H.; Stefanello da Silveira, A.P.; Silva Nacer, R.; Rodrigues de Souza, F.; Cardoso, C.A.L.; Boerngen de Lacerda, R.; Guterres, Z.d.R.; Oesterreich, S.A. Preclinical safety evaluation of the ethanolic extract from Campomanesia pubescens (Mart. ex DC.) O.BERG (guavira) fruits: analysis of genotoxicity and clastogenic effects. Food Funct 2018, 9, 3707-3717, https://doi.org/10.1039/c8fo01017j.

9. Baenas, N.; Wagner, A.E. Drosophila melanogaster as an alternative model organism in nutrigenomics. Genes Nutr 2019, 14, https://doi.org/10.1186/s12263-019-0641-y.

10. Oyeniran, O.H.; Ademiluyi, A.O.; Oboh, G. Comparative study of the phenolic profile, antioxidant properties, and inhibitory effects of Moringa (Moringa oleifera Lam.) and Almond (Terminalia catappa Linn.) leaves on acetylcholinesterase and monoamine oxidase activities in the head region of Fruitfly (Drosophila melanogaster Meigen) in vitro. J Food Biochem 2020, https://doi.org/10.1111/jfbc.13401.

11. Whittle, C.A.; Extavour, C.G. Selection shapes turnover and magnitude of sex-biased expression in Drosophila gonads. BMC Evol Biol 2019, 19, https://doi.org/10.1186/s12862-019-1377-4.

12. Lee, J.; Park, J.; Park, H.; Youn, D.-H.; Lee, J.; Hong, S.; Um, J.-Y. Synergistic effect of Bupleuri radix and Scutellariae radix on adipogenesis and AMP-Activated Protein Kinase: A Network Pharmacological Approach. Evid Based Complement Alternat Med 2018, 2018, https://doi.org/10.1155/2018/5269731.

13. Fu, Y.; Yang, J.-C.; Cunningham, A.B.; Towns, A.M.; Zhang, Y.; Yang, H.-Y.; Li, J.-W.; Yang, X.-F. A billion cups: The diversity, traditional uses, safety issues and potential of Chinese herbal teas. J Ethnopharmacol 2018, 222, 217-228, https://doi.org/10.1016/j.jep.2018.04.026.

14. Ichim, M.C.; Häser, A.; Nick, P. Microscopic authentication of commercial herbal products in the globalized market: potential and limitations. Front Pharmacol 2020, 11, https://doi.org/10.3389/fphar.2020.00876.

15. Abolaji, A.O.; Adedara, A.O.; Adie, M.A.; Vicente-Crespo, M.; Farombi, E.O. Resveratrol prolongs lifespan and improves 1-methyl-4-phenyl-1,2,3,6-tetrahydropyridine-induced oxidative damage and behavioural deficits in Drosophila melanogaster. Biochem Biophys Res Commun 2018, 503, 1042-1048, https://doi.org/10.1016/j.bbrc.2018.06.114. 
16. Abolaji, A.O.; Fasae, K.D.; Iwezor, C.E.; Aschner, M.; Farombi, E,O. Curcumin attenuates copper-induced oxidative stress and neurotoxicity in Drosophila melanogaster. Toxicol Rep 2020, 7, 261-268, https://doi.org/10.1016/j.toxrep.2020.01.015.

17. Abolaji, A.O.; Kamdem, J.P.; Lugokenski, T.H.; Nascimento, T.K.; Waczuk, E.P.; Farombi, E.O.; Loreto, E.L.; Rocha J.B.T. Involvement of oxidative stress in 4-vinylcyclohexene-induced toxicity in Drosophila melanogaster. J Free Radical Biol Med 2014, 71, 99-108, http://doi.org/10.1016/j.freeradbiomed.2014.03.014.

18. Abolaji, A.O.; Ajala, V.O.; Adigun, J.O.; Adedara, I.A.; Kinyi, H.W.; Farombi, E.O. Protective role of resveratrol, a natural polyphenol, in sodium fluoride-induced toxicity in Drosophila melanogaster. Exp Biol Med (Maywood) 2019, 244, 1688-1694, https://doi.org/10.1177/1535370219890334.

19. Ellman, G.L. Tissue sulfhydryl groups. J Arch Biochem Biophys 1959, 82, 70-77, http://doi.org/10.1016/0003-9861(59)90090-6.

20. Habig, W.H.; Jakoby, W.B. Assays for differentiation of glutathione-S-transferase. Methods Enzymol 1981, 77, 398-405, http://doi.org/10.1016/s0076-6879(81)77053-8.

21. Ellman, G.; Courtney, K.; Andres, J.V.; Featherstone, R. A new and rapid colorimetric determination of acetylcholinesterase activity. Biochem Pharmacol 1961, 7, 88-95, https://doi.org/10.1016/00062952(61)90145-9.

22. Eleftherianos, I.; More, K.; Spivack, S.; Paulin, E.; Khojandi, A.; Shukia, S. Nitric oxide levels regulate the immune response of Drosophila melanogaster reference laboratory strain to bacterial infections. Infect Immun 2014, 82, 69-81, https://doi.org/10.1128/IAI.02318-14

23. Ecker, A.; Gonzaga, T.K.S.d.N.; Seeger, R.L.; Santos, M.M.d.; Loreto, J.S.; Boligon, A.A.; Meinerz, D.F.; Lugokenski, T.H.; Rocha, J.B.T.d.; Barbosa, N.V. High-sucrose diet induces diabetic-like phenotypes and oxidative stress in Drosophila melanogaster: Protective role of Syzygium cumini and Bauhinia forficata. Biomed Pharmacother 2017, 89, 605-616, https://doi.org/10.1016/j.biopha.2017.02.076.

24. Yuan, Y.; Yu, M.; Zhang, B.; Liu, X.; Zhang, J. Comparative nutritional characteristics of the three major Chinese Dendrobium species with different growth years. PLoS One 2019, 14, https://doi.org/10.1371/journal.pone.0222666.

25. Allkin, B. Useful Plants - Medicines: At Least 28,187 Plant Species are Currently Recorded as Being of Medicinal Use. In: State of the World's Plants. Willis, K.J. ed. London (UK): Royal Botanic Gardens, Kew; 2017.

26. Halmenschelager, P.T.; da Rocha, J.B.T. Biochemical $\mathrm{CuSO}_{4}$ toxicity in Drosophila melanogaster depends on sex and developmental stage of exposure. Biol Trace Elem Res 2019, 189, 574-585, https://doi.org/10.1007/s12011-018-1475-y.

27. Marina, R.P.; Micheal, J.H.; Yann, S.M. Acetylcholine as a neuromodulator: cholinergic signalling shapes nervous system function and behaviour. J. Neron 2012, 76, 116-129, http://doi.org/10.1016/j.neuron.2012.08.036.

28. Balcerczyk, A.; Grzelak, A.; Janaszewska, A.; Jakubowski, W.; Koziol, S.; Marszalek, M.; Rychlik, B.; Soszynski, M.; Bilinski, T.; Bartosz, G. Thiols as major determinants of the total antioxidant capacity. Biofactors 2003, 17, 75-82, https://doi.org/10.1002/biof.5520170108.

29. Adesanoye, O.A.; Abolaji, A.O.; Faloye, T.R.; Olaoye, H.O.; Adedara, A.O. Luteolin-supplemented diets ameliorates Bisphenol A-Induced toxicity in Drosophila melanogaster. Food Chem Toxicol 2020, 142, https://doi.org/10.1016/j.fct.2020.111478.

30. Kozlov, A.; Koch, R.; Nagoshi, E. Nitric oxide mediates neuro-glial interaction that shapes Drosophila circadian behavior. PLoS Genet 2020, 16, https://doi.org/10.1371/journal.pgen.1008312.

31. Kale, O.E.; Akinpelu, O.B.; Bakare, A.A.; Yusuf, F.O.; Gomba, R.; Araka, D.C.; Ogundare, T.O.; Okolie, A.C.; Adebawo, O.; Odutola, O. Five traditional Nigerian Polyherbal remedies protect against high fructose fed, Streptozotocin-induced type 2 diabetes in male Wistar rats. BMC comple and Altern M 2018, 18, https://doi.org/10.1186/s12906-018-2225-6. 